\title{
Effect of bulb size on selected morphological characteristics of seed stalks, seed yield and quality of onion (Allium cepa L.) seeds
}

\author{
Maria Morozowska ${ }^{1}$, Roman Hotubowicz ${ }^{2}$ \\ ${ }^{1}$ Department of Botany, Poznań University of Life Sciences \\ Wojska Polskiego 71C, 60-625 Poznań, Poland \\ ${ }^{2}$ Department of Horticulture Seed Science and Technology \\ Poznań University of Life Sciences \\ Szamotulska 28, 62-081 Przeźmierowo, Poland \\ e-mail: mariamor@up.poznan.pl
}

Key words: 1000 seeds weight, onion inflorescence, seed germination, vegetable seeds

\section{ABSTRACT}

In the years $2002-2004$ research was carried out on the effect of onion (Allium сера L.) 'Wolska' bulb size on selected morphological characteristics of seed stalks, seed yield and quality. Commercial bulbs (vernalised, one-year-old mother bulbs) were divided into three groups: small, medium and large, with diameters of 4.2-5.3 cm, 5.4-6.3 $\mathrm{cm}$ and 6.4-8.5 cm, respectively. Then, the bulbs of each group were planted in the field and grown routinely with the purpose of producing seeds. The following characters were measured on the seed stalks: number and height of seed stalks grown out from one bulb, the seed stalks' diameter at the height of $10 \mathrm{~cm}$ above the ground, the diameter of the inflorescence, seed yield from a single 
stalk and from the entire plant, the weight of 1000 seeds, number of seeds in $1 \mathrm{~g}$, length and width of the seeds, length and width of the embryos, and germination energy and capacity. Our experiments showed a significant influence of bulb size on the number of seed stalks and the inflorescence diameter. It was discovered that the big bulbs gave larger numbers of seed stalks than the seed stalks grown from the medium and small ones. Small bulbs gave seed stalks with smaller inflorescences than the medium and large ones. The bulb size had no effect on the seed stalk height or their diameter when measured at the level of $10 \mathrm{~cm}$ above the ground. The bulb size also did not affect seed yield per one seed stalk, but it did affect the seed yield obtained from the entire plant, which was bigger for plants grown from large bulbs in comparison with the small ones. The size of the bulbs had no effect on either the weight of 1000 seeds or the number of seeds in $1 \mathrm{~g}$. It did not affect either the seed and embryo length and width or the seed germination energy and capacity.

\section{INTRODUCTION}

The onion is one of the most important vegetable species in the world. Its production area and amount, in both the European Union (EU) and Poland in recent years, despite some fluctuations, has remained at a consistently high level (Juszczak 2005, Anonim 2007, 2008). The onion market is characterised by large numbers of cultivars and strong competition. For this reason, many seed companies today have creative breeding programmes, in which they multiply and trade onion seeds (Hołubowicz et al. 2002). The onion's seed size and weight affect the subsequent germination and final yield (Gamiely et al. 1990).

In this situation, many breeders (seed companies) transfer onion seed production to areas with optimal climate conditions in order to lower the natural risk of losing crops (Hołubowicz 2007). They try, at the same time, to simplify onion seed production technology, so they can eventually, without losing seed quality, lower their price. Their effectiveness is caused by many factors (George 1985). Amongst the more important ones are plant health status, number of seed stalks growing out from one bulb (Korohoda 1974, Doruchowski 2000), the growth dynamics of the seed stalks themselves (Hołubowicz 1998, Hołubowicz et al. 2002) and procedures applied to the seeds before sowing (Hore et al. 1988, Murray et al. 1992).

The main purpose of this experiment was to find out how the bulb size affects some morphological characters of seed stalks, seed yield per plant and its quality. 


\section{MATERIAL AND METHODS}

The materials for the experiment were onion (Allium cepa L.) 'Wolska' mother bulbs from a commercial seed plantation belonging to the seed company "Spójnia" - Horticultural Plant Breeding and Seed Production in Nochowo n. Poznań (Western Poland). The cultivar used in the experiment is the oldest and one of the most important onion cultivars in Poland. It is a late cultivar, with white, slightly flatter bulbs covered with light yellow skin. It has white, juicy flesh and a delicate taste. It is resistant to rotting and easy to store. In seed production, for many years, in the conditions of Poland, it has been giving high yields of well-germinating seeds.

The research was carried out in the years 2002 - 2004 in the Baranowo Agricultural Experiment Station belonging to the Poznan University of Life Sciences. The field used had podzolic soil created from clay sands and located on a light clay with a humus level of $0.9-1.0 \%$. The experiment was begun in a random-plot design, each plot of the size of $6.4 \times 3.0 \mathrm{~m}$, in three replications. On the field of the experiments, in the previous years, sweet pea (2002), common bean (2003) and cereals (2004) were produced. Before planting, the bulbs were divided into three groups: small, medium and large with bulb diameters of 4.2-5.3 cm, 5.4-6.3 cm and 6.4-8.5 cm, respectively (Fig. 1). On each plot, 90 selected bulbs were hand-planted in a spacing of $50 \times 20 \mathrm{~cm}$. Then, the plants were cultivated routinely with the purpose of producing seeds using standard fertilisation, selection as well as plant protection.

During vegetation, the following seed stalk characteristics were measured for 30 plants from each plot: number and height of seed stalks grown from one bulb, the seed stalks' diameter at a height of $10 \mathrm{~cm}$ above the ground and the diameter of the inflorescence. After the maturation and harvest of seeds, the following characteristics were measured: seed yield from a single stalk and from the entire plant for 30 plants in each plot, weight of 1000 seeds calculated in eight replications of 100 seeds each and number of the seeds in $1 \mathrm{~g}$. Then, selected morphological and anatomical characteristics of the seeds were also measured. These were: length and width of the seeds as well as the length (the distance between the apex of the radicula and the farthest embryo point located on the long axis of the seed, which is further called the embryo 'length') and width of the embryo measured on the seed's longitudinal sections, done by hand with a blade (Fig. 2). The measurements were taken in three replications for each group of bulbs, with each replication consisting of 10 individual seeds. After post-harvest drying, four weeks after the harvest the seeds were also tested for energy and capacity of germination using the routine method accepted by the International Seed Testing Association (ISTA 1999). 
The discovered data were used to carry out a single factor variance analysis. The significant differences were calculated using the Duncan test at a significance level of $\mathrm{p}=0.05$.

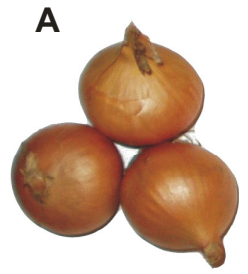

$\overline{1 \mathrm{~cm}}$
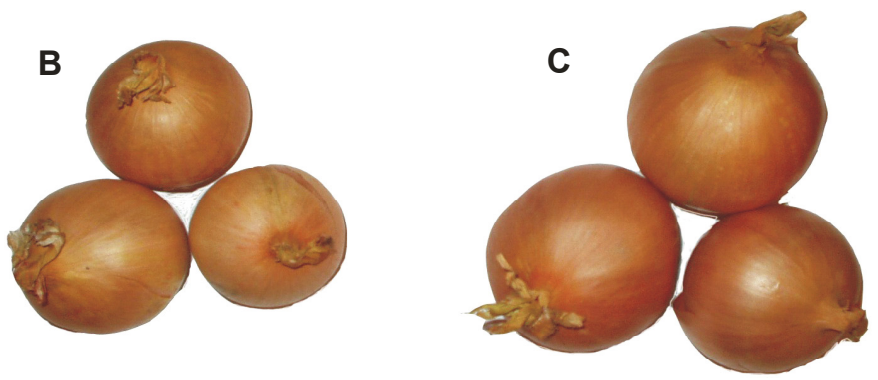

Fig. 1. Onion 'Wolska' bulbs: A - small; B - medium; C - large

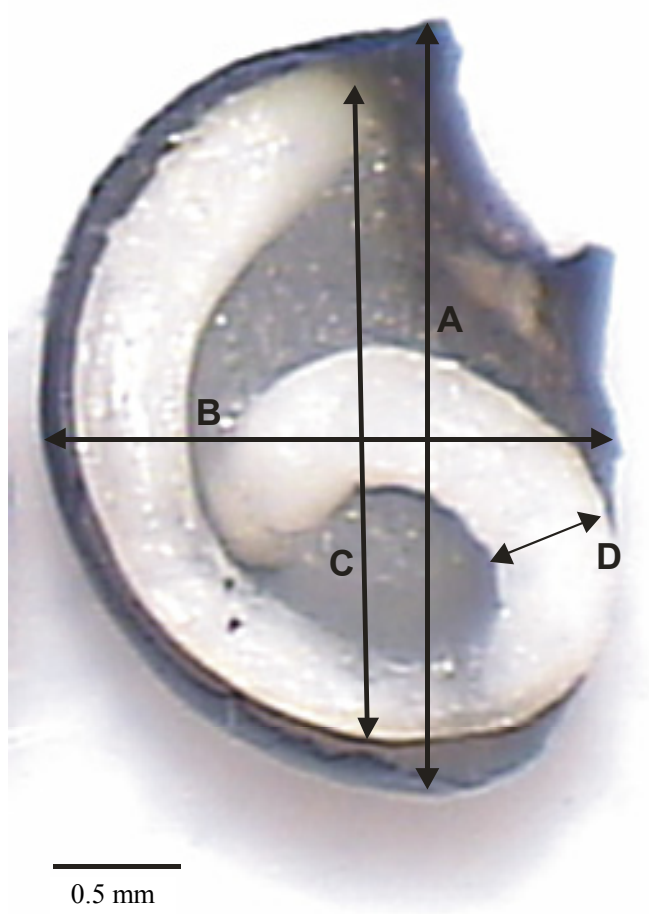

Fig. 2. Longitudinal section of onion 'Wolska' seed with the measurement process for the seeds' (A; B) and embryos' (C; D) lengths and widths 


\section{RESULTS AND DISCUSSION}

The weather conditions during length of the experiments, in terms of onion seed production, should be considered as medium good or good. The year 2002 was considered a medium good one. At first, a long winter delayed the start of bulb planting. Then, a draught in May seriously further delayed the plants' growth. However, the weather in the second half of May improved significantly (it was warm and rainy) and the plants soon caught up with the vegetation. Still, high levels of precipitation and storms with heavy winds in the blooming period led to poor bees flying, which resulted in a lower than normal seed set. Although rains at the end of July and hot weather in August were favourable conditions for heavy, dry and well germinating seeds, the final seed yields were still not high. The year of 2003 was in this aspect a good one. At first, it looked like a bad year due to a draught at the end of April and the beginning of May, which seriously delayed plant vegetation. Moreover, strong rains at the beginning of July weakened the seed set. However, in the middle of July the weather significantly improved and rains by the end of July helped in the good setting and fulfilling of the seeds, which resulted in good seed yield per plant. In turn, draught and hot weather at the end of August resulted in good drying of the seeds on the plants. The year 2004 was medium good for onion seed production. Although cold weather in June significantly delayed the vegetation of plants, good, sunny weather during blooming time positively affected the seed set and final seed yield. It was that, despite the chill in the beginning of September, which seriously complicated and delayed seed harvest.

The research showed that some morphological characters of the seed stalks depended on the size of the bulbs used for planting (Table 1). If the bulbs were large, in the applied growing conditions, the number of seed stalks grown was significantly larger than in the medium and small ones. This was found in the three following years of the experiment and it was confirmed despite various weather conditions during seed production. This is in agreement with the results of other researchers (George 1985, McDonald and Copeland 1997, Doruchowski 2000, Hussain et al. 2001) as well as seed production practical consultants working on day-to-day basis on the onion seed fields (Korohoda 1974, Noga 1982). For practical seed production, only large onion bulbs count, because in the following three years they gave larger numbers of seed stalks. The bulb size, however, had no effect on the stalks' height (Table 1). This characteristic is always watched by onion seed growers. High seed stalks easily fall down, which causes losses in seed yield and often requires additional seed stalk shortening, which is done by spraying them with growth retardants (Rudolph 1988, Hołubowicz et al. 2002). 


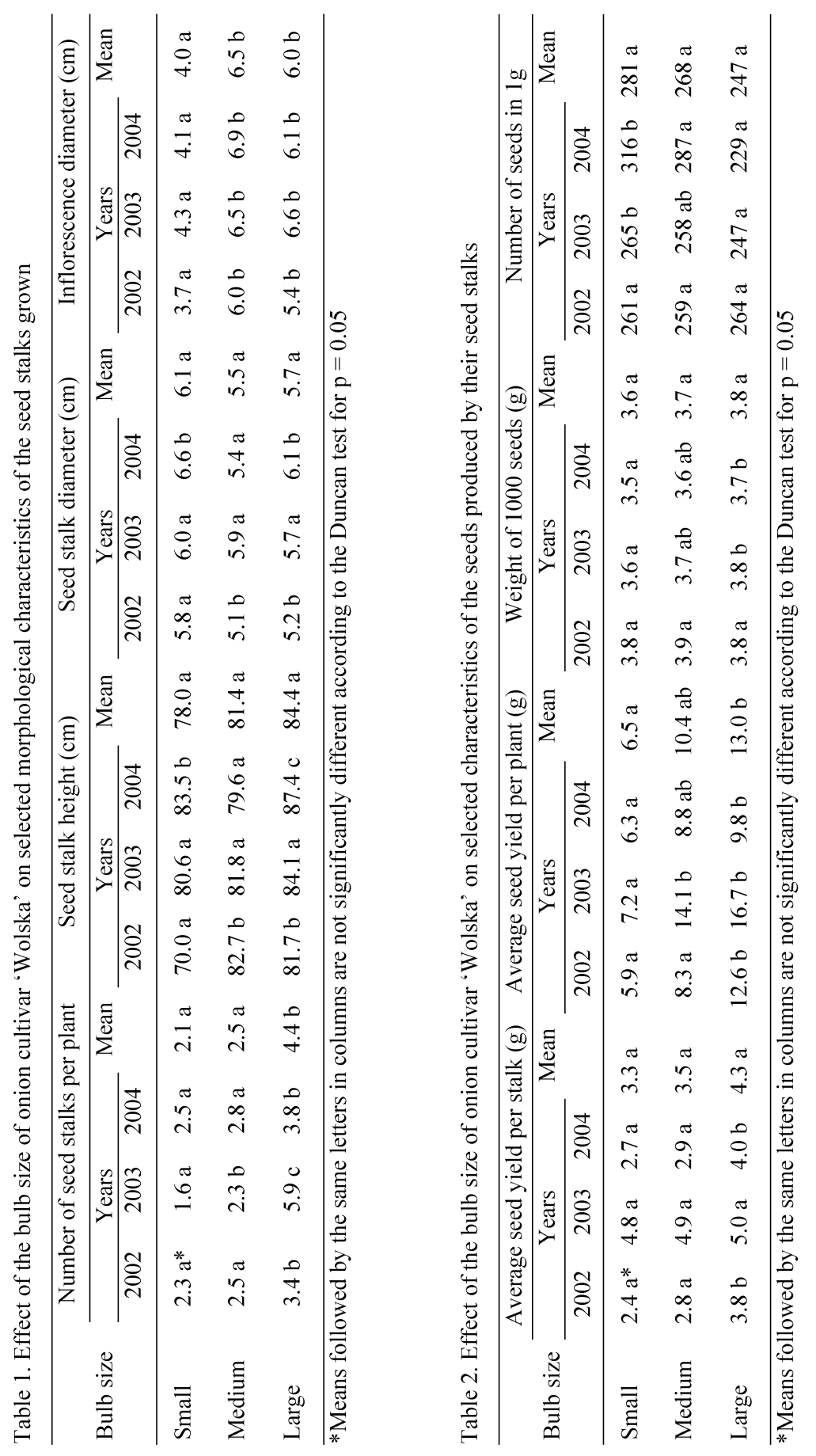


One would expect that lowering the seed stalks would result in an increase in their diameter in the bottom part particularly in terms of the fact that the lowering of onion seed stalks is accompanied by changes in the size of their cells (Hołubowicz 1998). However, this hypothesis was confirmed in the field in only one out of the three years of this experiment. The bulb size did affect the inflorescence size, however (Table 1). The seed stalks grown from small bulbs gave significantly smaller inflorescences than those grown from medium and large ones.

In the conditions of the applied plant spacing, the bulb size had a significant effect on the seed yield of the tested onion plants (Table 2). In two out of the three years of the experiment, the seed yield calculated per a single seed stalk was higher if the bulbs used were large, in comparison with the seed yield from the plants grown from medium and small bulbs. A very similar result was found for seed yield per plant, which was also higher for plants grown from large bulbs than from small ones. If the onion bulbs used were large, the seed yield per plant was twice as large than if the bulbs were small. The determined results are in agreement with the results of other authors (Korohoda 1974, Noga 1982, Aminopour and Mortazavi 2004) who received higher onion seed yields from plants grown from bigger bulbs. It also shows that in onion breeding, the direction of that breeding towards bigger bulb size not only improves commercial yield quality but also leads eventually to higher seed yield. The latter is of high interest to seed companies (Hołubowicz 2007). This is difficult because many onion cultivars that are highly yielding in commercial production are, at the same time, much less effective in seed setting. This results from the fact that in onion breeding the single growing point is preferable as it conditions good bulb equalisation, but on the other hand, it does not promote high seed yielding. In the present research, in two out of the three years of the experiment, the bulb size affected the seed quality measured by the weight of 1000 seeds (Table 2). Although the result of $3.8 \mathrm{~g}$ confirmed the earlier one given by Nasciemento and Freitas (2008), the mean values from the three years of the experiment did not vary significantly. The effect of onion bulb size on the weight of 1000 seeds was reported by Aminopour and Mortazavi (2004). A similar result was determined with the number of seeds in $1 \mathrm{~g}$. In two out of the three years of the experiment, the seeds grown on the seed stalks from small bulbs were smaller than the ones from the plants grown from the medium and large bulbs.

The bulb size did not significantly affect the morphological and anatomical characteristics of their seeds (Table 3). Only for the length of the seeds, in two out of the three years of the experiment, the seeds from the seed stalks grown from the large bulbs were longer than those from the plants grown from medium and small bulbs. Nevertheless, the mean values of this characteristic over three years did not differ significantly. Similarly, the size of the bulbs used for the production affected neither the seeds' width nor the embryos' length and width (Table 3). The observed stability of length and width of the onion's embryo confirmed earlier works on germination and the internal structure of the seeds of this species (Gray and Ward 1987, Hołubowicz et al. 1992, Gabriel et al. 1997). 


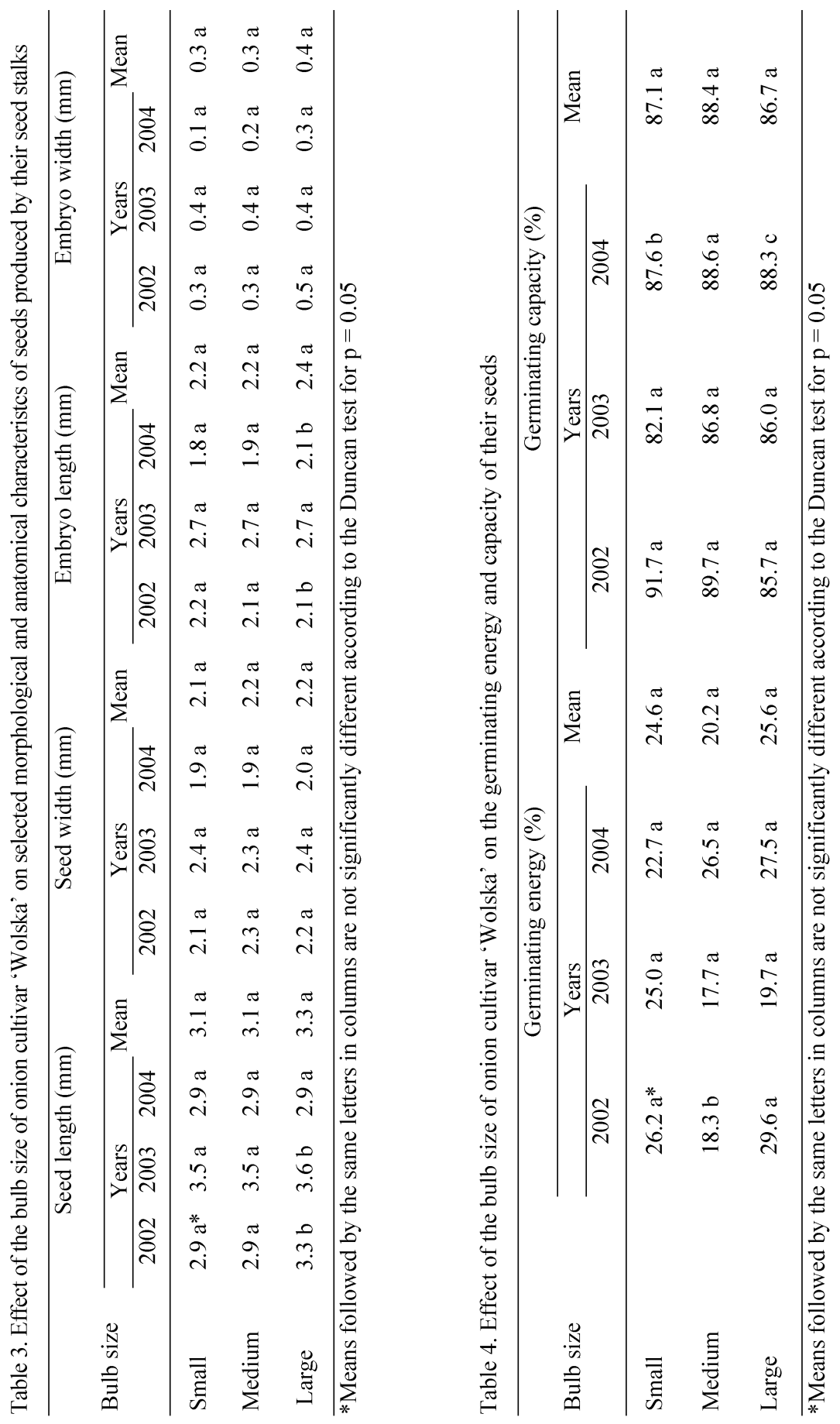


The size of the bulbs used in this experiment had no effect on either the germinating energy or the capacity of their seeds (Table 4). They germinated from $82.1 \%$ to $91.7 \%$, which should be considered as very good in the climate conditions of Poland. In average years in Poland onion seeds should not germinate less than 75\% (Doruchowski 2000).

The strategy developed by Polish plant breeding and seed production companies provides that since 2004, i.e. after joining the European Union, our country should specialize in a few strategic vegetables (Hołubowicz and Bralewski 2004). The onion has been amongst these species, and it is at present our most important exported vegetable (Juszczak 2005) as well as a leading species in breeding works and seed production (Hołubowicz and Bralewski 2008).

\section{CONCLUSIONS}

1. Large bulbs produced greater numbers of seed stalks than medium and small ones, and small bulbs produced seed stalks with smaller inflorescences than medium and large ones.

2. The bulb size affected neither the height of the seed stalks grown from them nor the diameter of the seed stalks, measured at $10 \mathrm{~cm}$ above the ground.

3. The seed yield from the plants grown from the large bulbs was higher than the seed yield from the plants grown from the small ones.

4. The bulb size used in the experiment affected neither the weight of 1000 seeds nor the number of seeds in $1 \mathrm{~g}$ produced from the grown seed stalks. It also did not affect either the length or width of the seeds or the embryos' length and width.

5. The bulb size had no effect on either energy or capacity of germination of their seeds.

\section{AKNOWLEDGEMENTS}

We are thankful to Ms. Ewa Pawlak for her technical help in carrying out the experiments and her assistance in the statistical analysis of the obtained data. 


\section{REFERENCES}

ANONIM, 2007. Produkcja warzyw w Unii Europejskiej w latach 2000 - 2006. Rynek owoców, warzyw. Analizy Rynkowe.

ANONIM, 2008. Produkcja cebuli w Polsce w latach 1997 - 2006. www.eBronisze.pl

AMINOPOUR R., MorTAZAVi B.A., 2004. Mother bulb size and planting pattern effects on seed quality of onion (Allium cepa L.) cv. Texas Early Grano 502. Seed Plant 20(1): 3, abstract.

DORUCHOWSKI R.W., 2000. Cebula zwyczajna (Allium cepa L. var. cepa Helm). In: „Nasiennictwo”. K.W. Duczmal and H. Tucholska (eds), PWRiL Oddział w Poznaniu 2: 252-263.

GABRIEL E.L., MAKUCH M.A., PiCCOlO R.J., 1997. Seed size, germination and bulb uniformity in onion (Allium cepa L.) cv. Volcatarce Inta. Acta Hort. 433: 573-584.

Gamiely S., Smittle D.A., Mills H.A., BanNA G.I., 1990. Onion seed size, weight, and element content affect germination and bulb yield. Hort. Sci. 25: 522-523.

GeORgE R.A.T., 1985. Vegetable Seed Production. Longan Group Ltd.

GRAY D., WARD J.A., 1987. A comparison of leek (Allium porrum) and onion (Allium cepa) seed development. Ann. Bot. 60: 181-187.

Holubowicz R., BRALEWSKi T.W., KacZMAREK M., ZHAO Y.B., 2002. Effect of etephon (CEPA) on the growth dynamics of seed stalk of onion (Allium cepa L.). Folia Hort. 14: 21-29.

HołUBOWICZ R., BRALEWSKI T.W., 2004. Strategie rozwoju ogrodniczych firm hodowlano-nasiennych po przystapieniu Polski do Unii Europejskiej. Folia Univ. Agric. Stetin. 239(95): 127-130.

HoŁubowicz R., BRALEWSKI T.W., 2008. Changes of the organization of the Polish seed sector after 1989. Proc. $43^{\text {rd }}$ and $3^{\text {rd }}$ Internl. Symp. on Agric. Opatia, Croatia: 412-415.

HOŁUBOWICZ R., 1998. Wpływ regulatorów wzrostu na wzrost pędów nasiennych i wytwarzanie nasion przez cebulę, por, marchew i sałatę. Roczn. AR Poznań, Ogrodn. 280: 1-113.

HoŁUBOwICZ R., 2007. Produkcja nasion roślin warzywnych. In: „Ogólna uprawa warzyw. M. Knaflewski (ed.), PWRiL, Poznań: 387-397. 
HORE J.K., PARIA N.C., SEN S.K., 1988. Effect of pre-sowing seed treatment on germination, growth and yield of onion (Allium cepa L.) var. Red Globe. Haryana J. Hort. Sci. 17: 83-87.

HUSSAIN S.W., ISHITAQ M., HUSSAIN S.A., 2001. Effect of different bulb size and planting dates on green leaf production of onion (Allium cepa L.) J. Biol. Sci. 1(5): 345-347.

ISTA, 1999. International Rules for Seed Testing. Seed Sci. Technol. 27, Supp. Rules.

JUSZCZAK K., 2005. Zmiany w produkcji warzyw gruntowych w Unii Europejskiej ze szczególnym uwzględnieniem cebuli. Roczn. Nauk. Stow. Ekon. Roln. i Agrobiz. 7: 114-119.

KOROHODA J., 1974. Produkcja nasion roślin warzywnych. PWRiL, Warszawa.

McDonald M.B., Copeland L.O., 1997. Seed Production. Principles and Practices. Chapmann \& Hall, New York, Paris, Washington.

MurRay G.A., Swensen J.B., Beaver G., 1992. Emergences of spring- and summer-planted onions following osmotic priming. Hort. Sci. 27: 409-410.

NASCIMENTO W.M., DE FREITAS R.A., 2008. Onion physiological seed quality in response to umbel maturation. Hort. Brasil. 26: 78-82.

NoGA H., 1982. Produkcja nasion cebuli. Biul. Warz. 25: 1-19.

RUDOLPH M., 1988. Beeinflussung der Standfestigkeit und andere Merkmale bei Samentragern der Zwiebel (Allium cepa L.) durch Wachstums-regulatoren. Arch. Gartenbau, Berlin 36: 65-76.

\section{WPŁYW WIELKOŚCI CEBUL NA WYBRANE CECHY MORFOLOGICZNE PĘDÓW NASIENNYCH ORAZ PLON I JAKOŚĆ NASION CEBULI (ALLIUM CEPA L.)}

Streszczenie: W latach 2002 - 2004 przeprowadzono badania nad wpływem wielkości wysadek cebuli (Allium cepa L.) odmiany 'Wolska' na wybrane cechy morfologiczne wyrosłych $\mathrm{z}$ nich pędów nasiennych. Cebule handlowe (zjaryzowane, jednoroczne wysadki) podzielono na 3 grupy: duże, średnie i małe, o średnicach odpowiednio: 4,2-5,3 cm, 5,4-6,3 cm oraz 6,4-8,5 cm. Cebule każdej $\mathrm{z}$ tych grup wysadzono $\mathrm{w}$ pole $\mathrm{i}$ uprawiono rutynowo $\mathrm{z}$ przeznaczeniem na nasiona. Zmierzono i oceniono następujące cechy: liczbę i wysokość pędów nasiennych wyrosłych z jednej cebuli, średnicę kwiatostanu, plon nasion z pojedynczego pędu i całej rośliny, masę 1000 nasion, liczbę nasion w 1 g, długość i szerokość nasion, długość i szerokość zarodka oraz energię i zdolność kiełkowania nasion. Stwierdzono, że z dużych cebul wyrosło więcej pędów nasiennych niż z cebul 
średnich i małych. Z małych cebul wyrosły pędy nasienne o mniejszej średnicy baldachu niż z cebul średnich i dużych. Wielkość cebul nie miała wpływu na wysokość pędów nasiennych oraz ich średnicę mierzoną na wysokości $10 \mathrm{~cm}$ od ziemi. Nie wpłynęła także na masę nasion uzyskanych z jednego pędu nasiennego. $\mathrm{Z}$ cebul dużych, w przeliczeniu na jedną roślinę, otrzymano większy plon nasion niż z cebul małych. Wielkość cebul nie wpłynęła natomiast na masę 1000 nasion, liczbę nasion w 1 g, długość i szerokość nasion, długość i szerokość zarodka oraz energię i zdolność kiełkowania nasion. 